\title{
IMPLICATION OF P53 MUTATION IN THE DYSREGULATION OF METABOLIC, APOPTOTIC AND OXIDANT/ANTIOXIDANT EQUILIBRIUM IN BREAST CANCER
}

\author{
BY \\ Mohamed A. Abd-Elaziz ${ }^{1}$, Ahmed A. Abdel Ghany ${ }^{1}$, Madiha M Zakhary ${ }^{2}$, Doaa W. \\ Maximus $^{3}$, Bakheet E. M Elsadek ${ }^{1, *}$, Hamada S. Qebesy ${ }^{1}$ \\ FROM \\ ${ }^{1}$ Department of Biochemistry, Faculty of Pharmacy, Al-Azhar University, P. O. Box \\ 71524, Assiut, Egypt. \\ ${ }^{2}$ Department of Biochemistry, Faculty of Medicine, Assiut University, P. O. Box \\ 71526, Assiut, Egypt. \\ ${ }^{3}$ Department of Surgical Oncology, South Egypt Cancer Institute, Assiut University, P. \\ O. Box 71526, Assiut, Egypt
}

\begin{abstract}
Breast cancer is the most worldwide frequent invasive tumor diagnosed in women. No single genomic or metabolic condition can be regarded as decisive for its progression. Whoever, few key players can be pointed out among them the tumor suppressor $\mathrm{p} 53$, one of the most frequent mutated gene in human malignances. The current study aimed to explore the influence of p53 mutation in the regulation of metabolic, apoptotic and oxidant/antioxidant pathways in breast cancer. In the present study, tumor specimens were obtained from 40 women in different grades of primary breast carcinoma. Another 10 non-malignant (marginal) breast tissue samples were used as controls. Both mutant p53 (mutp53) and Glyceraldehyde-3-phosphate dehydrogenase (GAPDH) proteins were assessed by Western blotting, while the mRNA levels of both the proapoptotic caspase- 3 and the antiapoptotic Bcl-2 were assessed by RT-PCR. The breast tissue levels of MDA, NO and GSH besides SOD activity were assayed calorimetrically. Results: Our results revealed that the tumor associated mutp53 overexpression is accompanied on the one hand by Bcl-2 up-regulation and caspase- 3 downregulation reflecting a dysfunctional apoptosis. On the other hand, excessive mutp53 was associated with GAPDH redundant-expression indicating an increased glycolysis. Significant disruptions in the oxidant/antioxidant balance were also coincided with tumor-inherent p53 mutation. Conclusion: Our findings concluded that p53 mutation in breast cancer could not only perturb the tumor suppressive potential of the wild type p53 (wtp53) but also could induce dominant-negative effects over its apoptotic and metabolic functions besides its endeavor in oxidant/antioxidant equilibrium. This overview could have valuable clinical applications in establishing novel strategies for cancer therapy.
\end{abstract}

Keywords: Breast cancer, P53, GAPDH, Caspase-3, Bcl-2, Oxidative stress 


\section{INTRODUCTION}

Breast cancer represents one of the most frequently diagnosed invasive women's malignancies with approximately 400.000 worldwide annual deaths (Walerych et al., 2012). In Egypt, breast cancer is one of the most common types of cancer, representing $15.4 \%$ of the total cancer cases among both sexes and $38.8 \%$ of all types of cancer in females (Ibrahim et al., 2014). In spite of the lower incidence than in the developed countries, a continuous increase in the incidence of breast cancer has been observed in Egypt with a substantial elevation in the associated mortality projection (Shulman et al., 2010). Furthermore, the current demographic trends favor the prospect that breast cancer will represent an eminent health issue among Egyptian women in the future (Dey, 2009).

It is suggested that tumor cells acquire their malignant lineaments through the accumulation of events linked to gene activation and/or inactivation over long periods of time. Of these genes is p53 tumor suppressor gene, a negative regulator of cell cycle with a pivotal role in the protection of the genome from the consequences of DNA damages. p53 inactivation was reported as a critical step in cellular transformation and its mutation was frequently reported in several types of cancers (Agrawal $\boldsymbol{e t}$ al., 2011; Olivier et al., 2010). The principle p53 protein exhibits a very short half-life and is present only in minute amounts in normal tissues and cells. However, malignant cells originated mutant p53 (mutp53) protein is usually a product of a missense point mutation in the p53 gene in which a single amino acid substitution leads to significantly prolonged half-life and increased accumulation of the mutp53 in the infected cells (Radha et al., 2014).

Besides its repertoire of activities, p53 has recently been reported to affect cellular metabolic pathways such as energy production, most likely via affecting the levels of series of gene products that regulate metabolic fates. For instance, p53 was reported to play a role in the slowdown of glycolysis and promotion of oxidative phosphorylation (Puzio-Kuter, 2011). Despite, glycolysis generates adenosine triphosphate (ATP) less efficiently than oxidative phosphorylation, malignant cells depend on glycolysis for ATP synthesis, even in the presence of abundant oxygen (Warburg effect) (Lu et al., 2015; Srinivasan et al., 2015). Accordingly, an upset energy metabolism has been considered as one of the "hallmarks of cancer" (Ganapathy-Kanniappan and Geschwind, 2013). Glyceraldehyde-3-phosphate dehydrogenase (GAPDH) is one of the most important enzymes involved in cell energy metabolism. It is a glycolytic enzyme which specifically catalyzes the reversible conversion of glyceraldehyde-3-phosphate (G-3-P) to 1, 3-diphosphoglycerate. In addition to its glycolytic effects, GAPDH participates in numerous cellular functions as nuclear tRNA export, DNA replication and repair, endocytosis, exocytosis, cytoskeletal organization, iron metabolism, carcinogenesis and cell death (Colell et al., 2009; Sheokand et al., 2014).

Another important function of p53 is its ability to activate apoptosis which if disrupted, can promote tumor progression and chemoresistance (Fridman and Lowe, 2003). The most important effectors of apoptosis are cysteine aspartic acid-specific proteases (caspases), pro-apoptotic proteins, which participate in a tightly regulated 
proteolytic cascade (Adams and Cory, 2002). Among the most extensively studied caspases is caspase-3 which was found to play important roles in both the death receptors pathway and the mitochondrial pathway (Bellarosa et al., 2001; Keane et al., 1999). Apoptosis is also governed by other effectors including the $B$ cell lymphoma 2 (Bcl-2) family proteins that include both anti- and pro-apoptotic proteins. A slight change in the dynamic balance of these proteins could either inhibit or promote cell death (Ola et al., 2011). Bcl-2 is a founder member of the Bcl-2 family of apoptosis regulator proteins which has been elucidated in tumor development by dysfunction in apoptotic pathways (Hanahan and Weinberg, 2000). It regulates the mitochondrial membrane potential and blocks the cytochrome-c and apoptosis inducing factor (AIF) release into the cytoplasm (Brunelle and Letai, 2009).

In spite of the above mentioned p53-linked cancer susceptibility and development, the risk factors associated with breast carcinogenesis may exert their effects via generation of reactive oxygen species (ROS) that are recognized to induce oxidative DNA damage and neoplastic transformation. Of late, ROS are being increasingly documented to be implicated in breast cancer development (Behrend et al., 2003; Kang, 2002). One of the most important functions of p53 is its involvement in the regulation of intracellular ROS levels (Ladelfa et al., 2011). The antioxidant function of p53 is represented in its ability to induce the expression of proteins acting to lower ROS levels, which prevents DNA damage and tumorgenesis under stressful conditions (Sablina et al., 2005).

The current study aimed to investigate the impact of mutp53 in breast cancer mainly, its role in metabolic regulation by investigating the glycolytic enzyme GAPDH, its apoptotic function by investigating the pro-apoptotic caspase- 3 and anti-apoptotic $\mathrm{Bcl}-2$ and its response to oxidative stress by investigating the tissue levels of some oxidative stress markers including malondialdehyde (MDA), nitric oxide (NO), reduced glutathione (GSH) and superoxide dismutase (SOD) activity. Another goal of the present study was to clarify the importance of GAPDH as a predictive biomarker of prognosis in breast cancer patients and to elucidate its role in tumor pathogenesis.

\section{PATIENTS AND METHODS}

\section{The study population}

The present study included 40 women with primary breast carcinoma in the age range of 33 to 63 years that were randomly selected from those admitted to the inpatient Surgical Oncology Department, South Egypt Cancer Institute, Assiut University, in the period between March 2013 and January 2015.

Prior to initiation, the current study was approved by the Research Committee at the Faculty of Medicine Assiut University (R. Nr. 02/02/2014). All participants were informed about the goal of the study and gave written consents for participation. Clinical data were obtained from patient's data sheets including age, tumor location, tumor size, tumor grade, evidence of axillary lymphadenopathy, presence of distant metastasis, local changes of aggressiveness and history of recurrence. 
Tumor tissue specimens were obtained from all subjects through either the use of a biopsy or following a surgical mastectomy. In addition, 10 normal (marginal) breast tissue samples were obtained to be used as controls. Immediately after surgical removal, each fresh tissue specimen was dissected into 4 portions. The first part was kept in $10 \%$ neutral buffered formalin for subsequent histological examinations and classification in accordance to the criteria of Elston and Ellis grading system (Elston and Ellis, 1993). The second part was immediately homogenized in ice-cold phosphate buffer saline $\mathrm{pH}$ 7.0 , centrifuge at $4000 \mathrm{rpm}$ for 15 minutes at $4{ }^{\circ} \mathrm{C}$ and subsequently stored at $-70^{\circ} \mathrm{C}$ until colorimetric assays of the oxidant/antioxidant indices. The third and the fourth portions were promptly frozen in liquid nitrogen and stored at $-70^{\circ} \mathrm{C}$ until use in Western blot and PCR assays.

\section{Investigation of mutp53 and GAPDH proteins expression using Western blotting}

Breast tissue samples were homogenized in ice-cold Tris- $\mathrm{HCl}$ buffer ( $\mathrm{pH} 7.4$ ) incorporating protease inhibitor cocktail (cell signaling technology, Inc, MA, USA) with the aid of Potter-Elvehjem rotor-stator homogenizer, fitted with a Teflon Pestle (Omni International, Kennesaw, GA, USA).

The total proteins in each breast tissue homogenate were thermally denatured at $95^{\circ} \mathrm{C}$ for 5 minutes in $2 \times$ Laemmli buffer containing 5\% (v/v) 2-mercaptoethanol. SDSPAGE electrophoresis was carried out by loading $50 \mu \mathrm{g}$ protein in each lane at 50 volts through the $(5 \%)$ stacking gel followed by 125 volts through the $(12.5 \%)$ resolving gel during around 2 hours and subsequently transferred to a PVDF membrane using T-77 ECL semidry transfer unit (Amersham Biosciences UK Ltd) for 2 hours. Immunoblotting was carried out via incubating the PVDF membrane in TBST buffer containing $0.1 \%$ Tween and $5 \%$ non-fat milk for one hour at $4 \stackrel{\circ}{\circ}$, followed by overnight incubation at $4 \mathrm{C}$ with mouse monoclonal anti-mutp53 anti body (Novus Biologicals, LLC, Littleton, CO, USA) at 1: 1500 dilution and mouse monoclonal anti-GAPDH antibody (Novus Biologicals, LLC, Littleton, CO, USA) at 1: 1000 dilution, for p53 and GAPDH respectively.

Subsequent to three times wash with TBST buffer, each membrane was incubated for an hour with an alkaline phosphatase-conjugated goat anti-mouse secondary antibody (Novus Biologicals, LLC, Littleton, CO, USA) at room temperature in a dilution of 1:5000. After four times wash with TBST buffer, the membrane bound antibody was visualized with a commercially available BCIP/NBT substrate detection kit (Genemed Biotechnologies, INC, CA, USA). Equivalent protein loading for each lane was confirmed by stripping and re-blotting each membrane against mouse monoclonal anti $\beta$-actin antibody (Santa Cruz Biotechnology, INC, CA, USA) at $4^{\circ} \mathrm{C}$ in a dilution of 1:5000. All analyses were repeated to assure reproducibility of the results. Corresponding quantification of each analysis was performed using image $\mathbf{J}$ software and expressed as a $\beta$-actin $\%$.

\section{Detection of caspase-3 and Bcl-2 mRNA by reverse transcriptase PCR (RT-PCR)}

Breast tissue samples were harvested in a specific lysis buffer supplied in total RNA purification kit (Jena Bioscience GmbH Jena, Germany) using Potter-Elvehjem 
rotor-stator homogenizer, fitted with a Teflon Pestle (Omni International, Kennesaw, GA, USA) according to the manufacturer's recommendations. To inhibit any active RNAses, the used stationary glass tube and inner tuning Teflon shaft of the homogenizer were washed with $0.1 \%$ diethylpyrocarbonate (DEPC) treated water, incubated overnight at $37^{\circ} \mathrm{C}$, and then autoclaved for 15 minutes to eliminate residual DEPC.

The isolated RNA purity (A260/A280 ratio) and concentration were determined using a GeneQuant 1300 Spectrophotometer (Uppsala, Sweden). RNA quality was confirmed by gel electrophoresis. The first-strand cDNA was then synthesized from 4 $\mu \mathrm{g}$ of total RNA using an Oligo (dT) 18 primer and RevertAid M-MuL V Reverse Transcriptase kit (Thermo Fisher Scientific Inc, Waltham, MA, USA). The mixture was incubated at $42^{\circ} \mathrm{C}$ for an hour, followed by incubation for 5 minutes at $70^{\circ} \mathrm{C}$ to terminate the reaction. The obtained cDNA was amplified by PCR. RT-PCR of $\beta$-actin was achieved in parallel as an internal control. The RT-PCR products were analyzed by electrophoresis using 2\% molecular screening agarose gel (Roche Diagnostics, GmbH, Mannheim, Germany), stained with ethidium bromide and visualized by UV light. Corresponding quantification of each gel analysis was further performed using Image $\mathrm{J}$ software and expressed as a $\beta$-actin $\%$. NCBI reference sequence, were used to design primers for human caspase-3, Bcl-2 and $\beta$-actin as shown in table 1 .

Table 1: The casapse-3, Bcl-2 and $\beta$-actin primers used for amplification in RTPCR detection

\begin{tabular}{|c|c|c|c|c|}
\hline Gene & Primer sequence & $\begin{array}{l}\text { Amplicon } \\
\text { size (bp) }\end{array}$ & $\begin{array}{l}\text { Annealing } \\
\text { temp. }{ }^{\circ} \mathrm{C}\end{array}$ & $\begin{array}{l}\text { Gen bank } \\
\text { accession } \\
\text { number }\end{array}$ \\
\hline Caspase-3 & $\begin{array}{l}\text { U: 5'- AGTTTCGTGAGTGCTCGCAG - } \\
\text { 3' } \\
\text { D: 5'- CTGAGGTTTGCTGCATCGAC - } \\
\text { 3, }\end{array}$ & 406 & $53{ }^{\circ} \mathrm{C}$ & NM_004346.3 \\
\hline Bcl-2 & $\begin{array}{l}\text { U: 5'- GGGCCACAAGTGAAGTCAAC } \\
-3 \text { ' } \\
\text { D: 5'- CGGTCTCCTAAAAGCAGGCA - } \\
\text { 3, }\end{array}$ & 982 & $53{ }^{\circ} \mathrm{C}$ & NM_14745.1 \\
\hline$\beta$-actin & $\begin{array}{l}\text { U: 5'-AGCGGGAAATCGTGCGTGAC } \\
\text { 3' } \\
\text { D: 5'-ACATCTGCTGGAAGGTGGAC - } \\
\text { 3, }\end{array}$ & 453 & $54{ }^{\circ} \mathrm{C}$ & NM_031144.3 \\
\hline
\end{tabular}

Assessment of tissue levels of oxidant/antioxidant markers

Lipid peroxidation was determined spectrophotometrically in breast tissue homogenates at 535 and $520 \mathrm{~nm}$ in the form of thiobarbituric acid reacting substance (TBARS) and is expressed as equivalents of MDA, using 1, 1, 3, 3 tetramethoxypropane as standard (Mihara and Uchiyama, 1978). Results were expressed as $\mu \mathrm{mol} / \mathrm{g}$ protein 
after estimation of the total protein content in the breast tissue homogenates (Lowry $\boldsymbol{e t}$ al., 1951).

GSH was assayed spectrophotometrically in the breast tissue homogenates at 412 $\mathrm{nm}$ using Ellman assay method (Ellman, 1959). Results were expressed as $\mu \mathrm{mol} / \mathrm{mg}$ protein. SOD activity in the breast tissue homogenates was assayed using kinetic procedures that based on the ability of SOD to inhibit the autooxidation of pyrogallol at alkaline medium ( $\mathrm{pH}$ 8.2) (Mathupala et al., 1997). The enzymatic activity is expressed as U/mg protein. One unit is equivalent to the amount of SOD required to inhibit 50\% of pyrogallol autooxidation. Based on the Griess reaction, NO was assayed spectrophotometrically in the breast tissue homogenates in the form of its stable metabolites, particularly, nitrite $\left(\mathrm{NO}_{2}\right)$ and nitrate $\left(\mathrm{NO}_{3}\right)$ (Sessa et al., 1994). Results were expressed as $\mu \mathrm{mol} / \mathrm{mg}$ protein.

\section{Statistical analysis}

Statistical analyses of the obtained data were carried out using GraphPad prism version 5.0 (Graph pad software San Diego, USA). Data comparisons were performed using analysis of variance (ANOVA) followed by Tukey s t-test. The levels of significance were accepted with $p<0.05$ and all relevant results were graphically displayed as mean \pm SEM.

\section{RESULTS}

\section{Clinical findings}

The clinicopathological features of the patients are summarized in Table 2 . Tumor samples were histopathologically typified according to the World Health Organization (WHO) "Classifications of Breast Tumors" into invasive ductal carcinoma (IDC), lobular carcinoma, and medullary carcinoma (Ellis et al., 1992). All cases of breast cancer were histopathologically classified into grade-I (well differentiated carcinoma), grade-II (intermediately differentiated carcinoma), and grade-III (poorly differentiated carcinoma) in accordance to the published criteria of the WHO (Elston and Ellis, 1993). 
Table 2: The clinicopathological features of the studied patients

\begin{tabular}{|c|c|c|c|}
\hline \multicolumn{2}{|c|}{ Clinicopathological feature } & Frequency per 40 case & Percent \\
\hline \multirow{3}{*}{ Age } & 35 years \& below & 6 & $16.6 \%$ \\
\hline & 36 to 50 years & 22 & $55.0 \%$ \\
\hline & Above 50 years & 12 & $28.4 \%$ \\
\hline \multirow{3}{*}{ Histological type } & Invasive ductal carcinoma & 34 & $85.0 \%$ \\
\hline & Lobular carcinoma & 4 & $10.0 \%$ \\
\hline & Medullary carcinoma & 2 & $5.0 \%$ \\
\hline \multirow{3}{*}{ Tumor grade } & Grade-I & 10 & $25.0 \%$ \\
\hline & Grade-II & 18 & $45.0 \%$ \\
\hline & Grade-III & 12 & $30.0 \%$ \\
\hline \multirow{3}{*}{ Tumor size } & $<2 \mathrm{~cm}$ & 11 & $27.5 \%$ \\
\hline & 2 to $5 \mathrm{~cm}$ & 16 & $40.0 \%$ \\
\hline & $>5 \mathrm{~cm}$ & 13 & $32.5 \%$ \\
\hline \multirow{2}{*}{ Lymph node status } & Present & 25 & $62.5 \%$ \\
\hline & Absent & 15 & $37.5 \%$ \\
\hline \multirow{2}{*}{ Affected breast } & Left & 26 & $65.0 \%$ \\
\hline & Right & 14 & $35.0 \%$ \\
\hline
\end{tabular}

\section{Immunoblotting detection of both mutp53 and GAPDH proteins}

As illustrated in Figure 1A, mutp53 protein showed over-expression in all grades of breast cancer in comparison to the normal marginal tissues. This tumor associated mutp53 over-expression was gradually increased from grade-I (low grade) to grade-III (high grade) (Figure 1A).

In comparison to the normal marginal tissues, GAPDH protein showed overexpression in all grades of breast cancer with gradual increase from grade-I (low grade) to grade-III (high grade) (Figure 1B). 

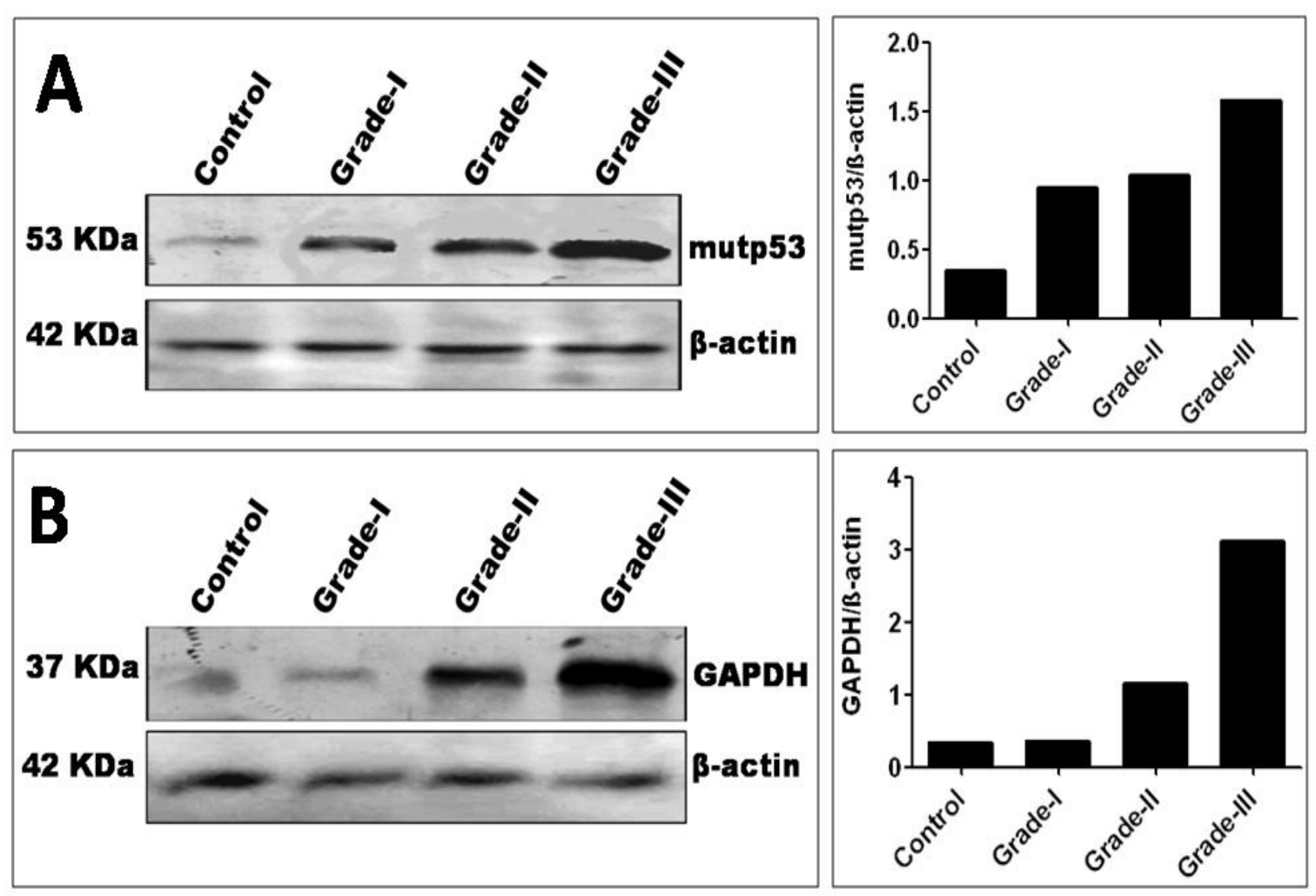

Figure 1: Representative Western blotting analysis of mutp53 (A) and GAPDH (B) in breast tissue homogenates of different groups. $\beta$-actin was used in parallel as an internal control. The right panels represent corresponding quantification of each analysis measured by Image $J$ software and expressed as a $\beta$-actin ratio.

\section{RT-PCR assessment of the mRNA levels of both caspase-3 and Bcl-2}

RT-PCR gel analysis showed an evident decrease in caspase-3 mRNA levels in all grades of breast cancer when compared to the normal marginal tissues (Figure 2A).

On the other hand, Bcl-2 mRNA levels were higher in tissues from all grades of breast carcinoma in comparison to the nonmalignant marginal tissues. Of note that, the observed decreases in caspase- 3 mRNA levels as well as the increase in Bcl-2 mRNA levels were relatively proportional to the tumor grade (Figure $2 \mathrm{~B}$ ). 


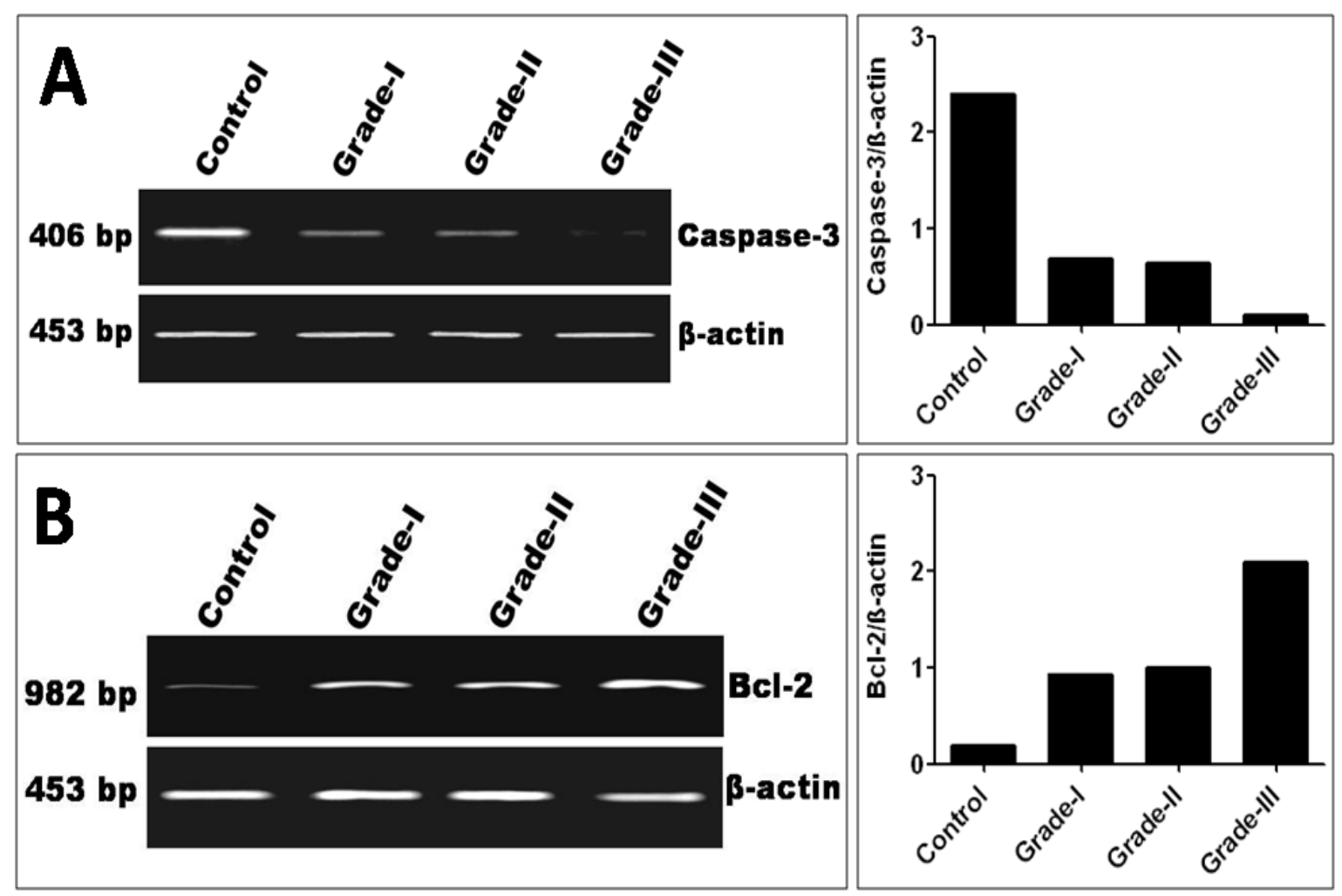

Figure 2: Representative RT-PCR detection of mRNA fragments of caspase-3 (A) and Bcl-2 (B) in breast tissue homogenates of different groups. $\beta$-actin was used in parallel as an internal control. The right panels represent corresponding quantification of each analysis measured by Image $\mathbf{J}$ software and expressed as a $\beta$-actin ratio.

\section{Assessment of oxidant/antioxidant markers}

In comparison to the nonmalignant control tissues, MDA and NO were significantly increased in grade-I ( $p<0.01$ and $p<0.01$ respectively), grade-II $(p<0.001$ and $p<0.001$, respectively) and grade-III ( $p<0.001$ and $p<0.001$, respectively) breast carcinoma. These increase in breast tissue contents of MDA and NO were significant in grade-II ( $p<0.01$ and $p<0.01$, respectively) and grade-III $(p<0.001$ and $p<0.001$, respectively) when compared to grade-I. In grade-III, breast tissue contents of MDA and NO showed significant increase ( $p<0.01$ and $p<0.01$, respectively) as compared to grade-II (Table 3).

Conversely, the GSH content and SOD activity were significantly reduced in the breast tissue homogenates of grade-I ( $p<0.05$ and $p<0.01$, respectively), grade-II ( $p<0.001$ and $p<0.001$, respectively), and grade-III $(p<0.001$ and $p<0.001$, respectively) in comparison to the control group (Table 3 ). When compared to grade-I, the decrease in GSH content and SOD activity were significant only in grade-III ( $p<0.001$ and $p<0.001$, respectively) but not in grade-II. In comparison to grade-II, the decrease in GSH content and SOD activity in the breast tissue homogenates was significant in grade-III ( $p<0.05$ and $p<0.01$, respectively). 
Table (3): Levels of MDA, NO, GSH and SOD as markers of oxidative stress in breast tissue homogenates of different groups

\begin{tabular}{|c|c|c|c|c|}
\hline & Control & Grade-I & Grade-II & Grade-III \\
\hline $\begin{array}{l}\mathrm{MDA}(\mu \mathrm{mol} / \mathrm{g} \\
\text { protein) }\end{array}$ & $10.46 \pm 0.92$ & $18.70 \pm 1.01^{* * *}$ & $26.37 \pm 1.52^{* * * *}$ & $35.00 \pm 2.20$ \\
\hline $\begin{array}{l}\mathrm{NO}(\mu \mathrm{mol} / \mathrm{mg} \\
\text { protein })\end{array}$ & $18.75 \pm 1.53$ & $46.29 \pm 3.64^{* *}$ & $72.66 \pm 5.50 * * * \cdot \cdot$ & $98.23 \pm 7.02^{* * *, \cdots, \circ \circ}$ \\
\hline $\begin{array}{l}\text { GSH }(\mu \mathrm{mol} / \mathrm{mg} \\
\text { protein })\end{array}$ & $14.70 \pm 1.07$ & $11.42 \pm 0.85^{*}$ & $8.59 \pm 0.69^{* * *}$ & $4.78 \pm 0.36^{* * *, \cdots, \circ}$ \\
\hline $\begin{array}{ll}\text { SOD } & (\mathrm{U} / \mathrm{mg} \\
\text { protein }) & \end{array}$ & $140.40 \pm 8.55$ & $109.80 \pm 7.34^{* *}$ & $86.03 \pm 3.82^{* * *}$ & $55.53 \pm 3.26^{* * *}, \cdots, \infty \circ$ \\
\hline
\end{tabular}

Data are presented as mean $\pm \operatorname{SEM}(n=10) . *, \bullet$ and $\circ$ indicate significant change from control, grade-I and grade-II, respectively. ${ }^{*},{ }^{\bullet}$ and ${ }^{\circ}$ indicate significant change at $\mathrm{p}<0.05,{ }^{* *},{ }^{\bullet}$ and ${ }^{\circ}$ indicate significant change at $\mathrm{p}<0.01 .^{* * * *},{ }^{\cdots}$ and ${ }^{\circ \circ 0}$ indicate significant change at $\mathrm{p}<0.001$. MDA, malonaldehyde; NO, nitric oxide; SOD, superoxide dismutase; GSH, reduced glutathione

\section{DISCUSSION}

Like the vast majority of other malignancies, breast cancer has a ramified complex heterogeneous genetic and biochemical background with no solitary definite metabolic or genomic implication. Up-to-date, some key players can be pointed out to exhibit a role in this regard; among them is p53 tumor suppressor gene (Amelio et al., 2016; Walerych et al., 2012). p53 is the most frequently mutated gene in human malignancies (Agrawal et al., 2011; Basu and Murphy, 2016). Mutant p53 (mutp53) has been reported to exhibit a longer half-life than the wild type p53 (wtp53) protein, leading to the accumulation of nonfunctioning p53 protein in the cell nucleus (Radha $\boldsymbol{e t}$ al., 2014).

In order to assess its role in the development and progression of breast cancer, the current study aimed to investigate the expression pattern of mutp53 in different grades of breast cancer in comparison to histologically normal tumor-surrounding tissues. Results of the current study have established that there was over-expression of mutp53 protein in all grades of breast cancer in comparison to the normal marginal tissues with gradual increase from grade-I to reach its maximum in grade-III. Similar findings were also reported in other investigations (Redondo et al., 2003 ; Skarlos et al., 2005). The currently underlined steadily increasing mutp53 expression in tumor tissues inspires that p53 mutation might be a decisive event in the development of breast cancer that is maintained during tumor progression after its initiation at the early phases of the disease. This can be explained by the fact that the majority of p53 missense mutations take place in the DNA binding domain (DBD) of p53 protein leading to marked alterations in the p53 tertiary structure and accordingly loss of its specific DNA-binding activity that in turn deactivate p53 as a transcription factor that directly regulates gene expression (Xu et al., 2011). On the basis of these findings, mutp53 is proposed to gain oncogenic functions, i.e., promote tumor growth and cancer cell survival. 
Another aspect of the current study was to investigate the impact of p53 mutation in the regulation of breast cancer cell metabolism mainly glycolysis, via assessment of the expression pattern of GAPDH, an important component of glycolysis. Our results revealed that there was an apparent over-expression of GAPDH in breast cancer tissues, especially grade-II and grade-III, in comparison to the marginal normal tissues suggesting tumor associated up-regulation of glycolysis. It is well known today that the increased glucose metabolism is an important feature of the progression of many types of cancers. This could be explained by the fact that cancer cells up-regulate a number of different pathways including glycolysis to keep up with the demands of providing biomass for rapidly dividing transformed cells to sustain growth and at the same time live under stressful hypoxic conditions (Vander Heiden et al., 2009).

According to the Warburg effect, cancer cell switch its metabolic pathways towards an increased dependence on glycolysis for ATP synthesis, even in the presence of abundant oxygen, rather than using the more effective oxidative phosphorylation (Lu et al., 2015; Srinivasan et al., 2015). This switch has even been termed a hallmark of cancer that explains how cancerous processes prepare substrates for active cell growth and division (Puzio-Kuter, 2011). Additionally, the apparent harmony between the increased rate of glycolysis, as evidenced by GAPDH over-expression and the p53 malfunction, as evidenced by mutp53 over-expression, could be explained by the fact that p53 retard glycolysis and reinforce oxidative phosphorylation opposing the Warburg effect. It plays this role via regulating series of genes that affect metabolic fates and metabolic products providing a mechanism of blocking tumorgenesis that is mechanistically different from either apoptosis or senescence (Bensaad and Vousden, 2007). However, loss of $\mathrm{p} 53$ functions in breast cancer due to mutation, as evidenced here by mutp53 over-expression, strongly confirm a switch from aerobic respiration to glycolysis. These metabolic alterations, particularly the metabolic reprogramming to aerobic glycolysis (i.e., the Warburg effect) and the reprogramming of mitochondrial metabolism, represent a hallmark of cancer that contributes to malignant transformation as well as the growth and maintenance of tumors (Hanahan and Weinberg, 2011; Ward and Thompson, 2012).

Another important goal of the current study was to explore the influence of p53 mutation in the apoptotic pathway in breast cancer. RT-PCR gel analyses showed marked decrease in the mRNA level of the pro-apoptotic caspae-3 concomitantly with apparent increase in in the mRNA level of the anti-apoptotic Bcl-2 in all grades of breast cancer in comparison to the non-neoplastic marginal tissues. The observed alterations in the mRNA levels of these apoptosis effectors commensurate with the tumor grade. These results are in agreement with previous reports that mutp53 enhance the expression of Bcl-2 protein levels in estrogen receptor positive breast cancer cells (Pratt et al., 2007). Tumor-derived mutp53 has also been reported to impair the activation of the procaspase- 3 resulting eventually in down-regulation of active caspase3 (Frank et al., 2011).

These findings strongly suggests that the caspase-3 down-regulation and/or Bcl2 up-regulation could be implicated in breast cancer development and progression via rendering breast cancer cells resistant to apoptosis and thus may affect the outcome and progression of the disease. Based on these results, we claimed that there was an 
entertaining association between p53, glycolysis, and apoptosis, where p53 mutation in breast cancer is accompanied by enhanced rate of glycolysis and dysfunctional apoptosis. This can be attributed to the fact that p53-mediated PUMA expression is restrained by high glucose level (Zhao et al., 2008). p53 inactivation and PUMA induction is initiated by glucose metabolism that then promote an antiapoptotic balance supporting cancer cell survival (Coloff $\boldsymbol{e t}$ al., 2011). Additionally, p53 hinders glycolysis and promotes oxidative phosphorylation by regulating the levels of a series of genes that are under its transcriptional control. Thus, p53 mutation can influence aspects of apoptosis, glycolysis and oxidative phosphorylation, and therefore is significantly important in contributing to the Warburg effect.

Finally, the present study examined the tissue levels of some oxidant/antioxidant markers to clarify their link with p53 mutation in breast cancer development and progression. Outcomes of our study revealed a significant increase in the tissue level of MDA, the lipid peroxidation product and NO, a free radical in all grades of breast cancer when compared to the non-malignant marginal tissues. This could be attributed to the tumor associated over-production of ROS. These results agree with previous studies which have shown increased lipid peroxidation and No levels in solid tumors and malignant cell lines including breast tumors (Kumaraguruparan et al., 2005; Tupurani et al., 2013). In addition, our results exhibited that the changes in the tissue levels of both MDA and NO were more pronounced in grade-III compared to grade-I and grade-II, indicating that there was a positive relation between their levels and tumor grade suggesting the involvement of ROS in tumor progression. On the other hand, the tumor associated increases in lipid peroxidation and NO levels were accompanied by obvious decrease in the antioxidant pool as manifested by diminished GSH levels and SOD activity in all grades of breast cancer tissues when compared to controls. This diminished GSH 1 levels and SOD activity are in accordance with previous records in breast cancer patients (Kumaraguruparan et al., 2002). We also observed that there was a negative relation between the tissue levels of these parameters and tumor grade suggesting that the defect in the antioxidant mechanism may contribute to tumor development and progression. Therefore, our results support the proposition that the generation of reactive oxygen and nitrogen species increase oxidative damage and decrease the antioxidant detoxifying capacity that could induce a high frequency of p53 mutations contributing to increased risk of cancer. This agree well with the results of some previous reports which showed that the expression of mutp53 was correlated to increased lipid peroxidation and lowered antioxidant pool in the breast cancer patients (Milicevic et al., 2014).

In conclusion, these findings collectively propose that the harmonious interaction between p53 mutation and each of up-regulated glycolysis and dysfunctional apoptosis as well as the oxidant/antioxidant imbalance might be potentially implicated in the pathogenesis and invasiveness of breast cancer. Future investigations of breast cancer biology from this overview could have valuable clinical applications not only in reconnoitering new tumor markers but also in the establishing novel strategies for cancer therapy. 


\section{FINANCIAL DISCLOSURE}

This research did not receive any specific grant from funding agencies in the public, commercial, or not-for-profit sectors.

\section{DECLARATION OF INTEREST SECTION}

The authors report no declarations of interest.

\section{ACKNOWLEDGEMENTS}

The authors are grateful to the members of Pathology Department, Assiut University for performing the histopathological examinations as well as reading and interpreting of the sections.

\section{REFERENCES}

Adams J and Cory S (2002): Apoptosomes: engines for caspase activation. Current opinion in cell biology; 14: 715-720.

Agrawal N, Frederick MJ, Pickering CR, Bettegowda C, Chang K, Li RJ, Fakhry C, Xie $T$ - $X$, Zhang $J$ and Wang $J$ (2011): Exome sequencing of head and neck squamous cell carcinoma reveals inactivating mutations in NOTCH1. Science; 333: 1154-1157.

Amelio I, Knight R, Lisitsa A, Melino G and Antonov A (2016): p53MutaGene: an online tool to estimate the effect of p53 mutational status on gene regulation in cancer. Cell Death Dis; 7: 1-6.

Basu S and Murphy $M$ (2016): Genetic Modifiers of the p53 Pathway. Cold Spring Harb Perspect Med; 6: 1-6.

Behrend L, Henderson G and Zwacka R (2003): Reactive oxygen species in oncogenic transformation. Biochemical Society Transactions; 31: 1441-1444.

Bellarosa D, Ciucci A, Bullo A, Nardell F, Manzini S, Maggi C and Goso C (2001): Apoptotic events in a human ovarian cancer cell line exposed to anthracyclines. J Pharmacol Exp Ther; 296: 276-228.

Bensaad K and Vousden KH (2007): p53: new roles in metabolism. Trends in cell biology; 17: 286-291.

Brunelle JK and Letai A (2009): Control of mitochondrial apoptosis by the Bcl-2 family. Journal of cell science; 122: 437-441.

Colell A, Green DR and Ricci J-E (2009): Novel roles for GAPDH in cell death and carcinogenesis. Cell Death \& Differentiation; 16: 1573-1581. 
Coloff JL, Mason EF, Altman BJ, Gerriets VA, Liu T, Nichols AN, Zhao Y, Wofford JA, Jacobs SR and Ilkayeva $O$ (2011): Akt requires glucose metabolism to suppress puma expression and prevent apoptosis of leukemic T cells. Journal of Biological Chemistry; 286: 5921-5933.

Dey S. (2009) Urban-rural differences of female cancers in Gharbiah, Egypt. National Cancer Institute.

Ellis I, Galea M, Broughton N, Locker A, Blamey $R$ and Elston C (1992): Pathological prognostic factors in breast cancer. II. Histological type. Relationship with survival in a large study with long-term follow-up. Histopathology; 20: 479-489.

Ellman GL (1959): Tissue sulfhydryl groups. Arch Biochem Biophys; 82: 70-77.

Elston E and Ellis I (1993): Method for grading breast cancer. Journal of clinical pathology; 46: 189.

Frank A, Pietsch E, Dumont P, Tao J and Murphy M (2011): Wild-type and mutant p53 proteins interact with mitochondrial caspase-3. Cancer Biology \& Therapy; 11: 740-745.

Fridman J and Lowe S (2003): Control of apoptosis by p53 Oncogene 22: 9030-9040.

Ganapathy-Kanniappan S and Geschwind J (2013): Tumor glycolysis as a target for cancer therapy: progress and prospects. Mol Cancer; 12: 4598-4512.

Hanahan D and Weinberg RA (2000): The hallmarks of cancer. cell; 100: 57-70.

Hanahan D and Weinberg RA (2011): Hallmarks of cancer: the next generation. cell; 144: 646-674.

Ibrahim A, Khaled H, Mikhail N, Baraka H and Kamel H (2014): Cancer incidence in egypt: results of the national population-based cancer registry program. $J$ Cancer Epidemiol; 2014: 1-18.

Kang D-H (2002): Oxidative stress, DNA damage, and breast cancer. AACN Advanced Critical Care; 13: 540-549.

Keane M, Ettenberg S, Nau M, Russell E and Lipkowitz S (1999): Chemotherapy augments TRAIL-induced apoptosis in breast cell lines. Cancer research; 59: 734-741.

Kumaraguruparan R, Kabalimoorthy $J$ and Nagini $S$ (2005): Correlation of tissue lipid peroxidation and antioxidants with clinical stage and menopausal status in patients with adenocarcinoma of the breast. Clinical biochemistry; 38: 154-158. 
Kumaraguruparan $R$, Subapriya $R$, Kabalimoorthy $J$ and Nagini $S$ (2002): Antioxidant profile in the circulation of patients with fibroadenoma and adenocarcinoma of the breast. Clinical Biochemistry; 35: 275-279.

Ladelfa MF, Toledo MF, Laiseca JE and Monte M (2011): Interaction of p53 with tumor suppressive and oncogenic signaling pathways to control cellular reactive oxygen species production. Antioxidants \& redox signaling; 15: 1749-1761.

Lowry O, Rosebrough N, Farr A and Randall R (1951): Protein measurement with the Folin phenol reagent. J.Biol. Chem; 193: 265-275.

Lu J, Tan $M$ and Cai $Q$ (2015): The Warburg effect in tumor progression: mitochondrial oxidative metabolism as an anti-metastasis mechanism. Cancer Lett.; 356: 156-164.

Mathupala SP, Heese C and Pedersen PL (1997): Glucose catabolism in cancer cells. The type II hexokinase promoter contains functionally active response elements for the tumor suppressor p53. Journal of Biological Chemistry; 272: 2277622780 .

Mihara $M$ and Uchiyama $M$ (1978): Determination of malonaldehyde precursor in tissues by thiobarbituric acid test. Anal Biochem; 86: 271-278.

Milicevic Z, Kasapovic J, Gavrilovic L, Milovanovic Z, Bajic V and SpremoPotparevic B (2014): Mutant p53 protein expression and antioxidant status deficiency in breast cancer. EXCLI Journal 13: 691-708.

Ola MS, Nawaz M and Ahsan H (2011): Role of Bcl-2 family proteins and caspases in the regulation of apoptosis. Molecular and cellular biochemistry; 351: 41-58.

Olivier M, Hollstein $M$ and Hainaut $P$ (2010): TP53 mutations in human cancers: origins, consequences, and clinical use. Cold Spring Harbor perspectives in biology; 2: 1-17.

Pratt M, White D, Kushwaha N, Tibbo E and Niu M (2007): Cytoplasmic mutant p53 increases Bcl-2 expression in estrogen receptor-positive breast cancer cells. Apoptosis; 12: 657-669.

Puzio-Kuter A (2011): The Role of p53 in Metabolic Regulation. Genes Cancer 2: 385391.

Radha RKN, Viswanathan $P$ and Krishnaswamy $B$ (2014): Histopathology and Prognostic Indices of Carcinoma Breast with Special Reference to p53 Marker. Journal of clinical and diagnostic research: JCDR; 8: FC04.

Redondo M, Garcia J, Rodrigo I, Villar E, González C and Morell M (2003 ): Expression of bax and p53 proteins in the tumorigenesis and progression of breast carcinomas. Tumour Biol; 24: 23-31. 
Sablina AA, Budanov AV, Ilyinskaya GV, Agapova LS, Kravchenko JE and Chumakov PM (2005): The antioxidant function of the p53 tumor suppressor. Nature medicine; 11: 1306-1313.

Sessa WC, Pritchard K, Seyedi N, Wang J and Hintze TH (1994): Chronic exercise in dogs increases coronary vascular nitric oxide production and endothelial cell nitric oxide synthase gene expression. Circ Res; 74: 349-353.

Sheokand N, Malhotra H, Kumar S, Tillu VA, Chauhan AS, Raje CI and Raje M (2014): Moonlighting cell-surface GAPDH recruits apotransferrin to effect iron egress from mammalian cells. Journal of cell science; 127: 4279-4291.

Shulman LN, Willett W, Sievers A and Knaul FM (2010): Breast cancer in developing countries: opportunities for improved survival. Journal of oncology; 2010.

Skarlos D, Gogas H, Kiriakou V, Margariti A, Kirkou E, Pavlaki K, Asimaki A, Toliou T, Tziortziotis D, Vamvouka $C$ and Fountzilas $G$ (2005): Evaluation of the prognostic value of $\mathrm{p} 53$ and $\mathrm{Bcl}-2$ in breast cancer patients participating in a randomized study with dose-dense sequential adjuvant chemotherapy (DSAC). Journal of Clinical Oncology; 23: 627-627.

Srinivasan S, Guha M and Avadhani $N$ (2015): Mitochondrial respiratory defects promote the Warburg effect and cancer progression. Mol Cell Oncol; 3: e1085120-e1085121.

Tupurani MA, Padala C, Kumar RG, Puranam K, Kumari S and Rani SH (2013): Oxidative stress/Nitrosative stress in breast cancer. Int J Anal Bio-Sci Vol; 1.

Vander Heiden M, Cantley L and Thompson C (2009): Understanding the Warburg effect: the metabolic requirements of cell proliferation. Science; 324: 1029-1033.

Walerych D, Napoli M, Collavin L and Del Sal G (2012): The rebel angel: mutant p53 as the driving oncogene in breast cancer. Carcinogenesis; 33: 2007-2017.

Ward PS and Thompson CB (2012): Metabolic reprogramming: a cancer hallmark even warburg did not anticipate. Cancer cell; 21: 297-308.

Xu J, Reumers J, Couceiro JR, De Smet F, Gallardo R, Rudyak S, Cornelis A, Rozenski J, Zwolinska A and Marine J-C (2011): Gain of function of mutant p53 by coaggregation with multiple tumor suppressors. Nature chemical biology; 7: 285-295.

Zhao Y, Coloff JL, Ferguson EC, Jacobs SR, Cui K and Rathmell JC (2008): Glucose metabolism attenuates p53 and Puma-dependent cell death upon growth factor deprivation. Journal of Biological Chemistry; 283: 36344-36353. 


\section{تأثير الطقرة الجينة في بروتين-به في عدم إنتظام التوازن الخاص بالاستقلاب وموت الخلايا

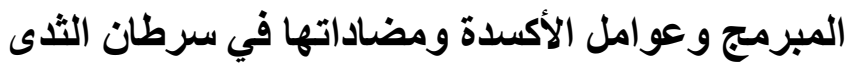

\section{للسادة الاكاترة}

'محمد أنور عبد العزيز - 'أحمد على عبد الغنى- كديحة محروس زخارى- 'دعاء وديع ماكسيموس- 'بخيت القط

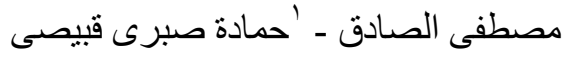

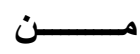

$$
\begin{aligned}
& \text { 'قسم الكيمياء الحيوية ـ كلية الصيدلة - جامعة الازهر - أسيوط } \\
& \text { "قسم الكيمياء الحيوية ـ كلية الطب - جامعة أسيوط } \\
& \text { "قسم جر احة الأور ام - معهد للأور ام بجنوب مصر - جامعة أسيوط }
\end{aligned}
$$

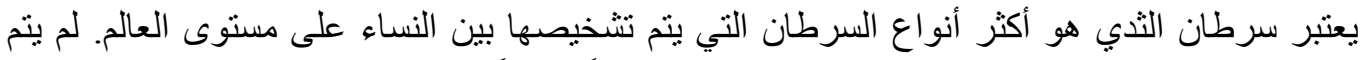

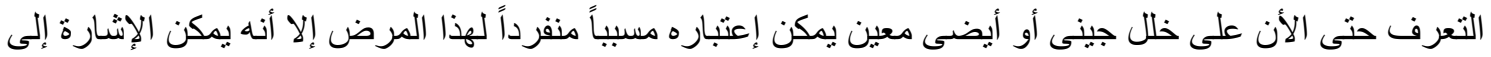

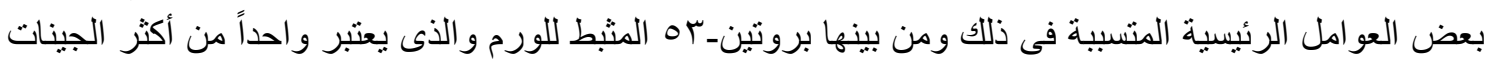

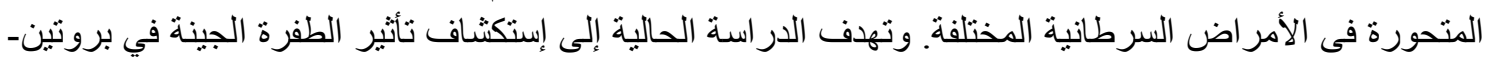

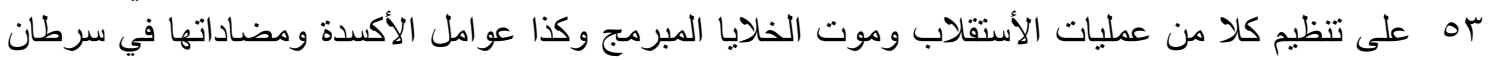

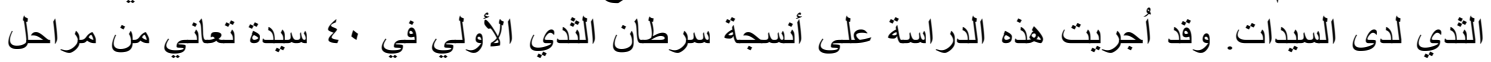

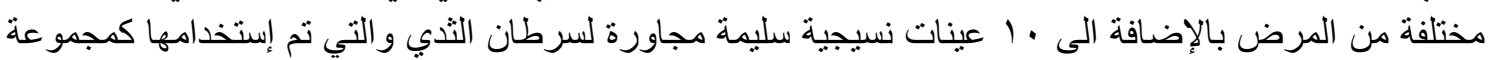

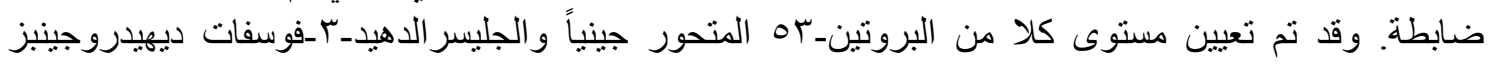

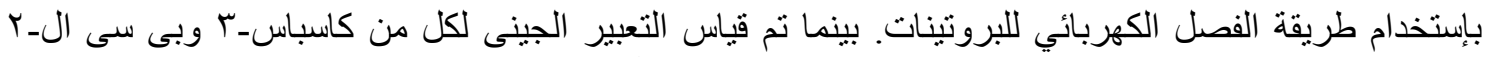

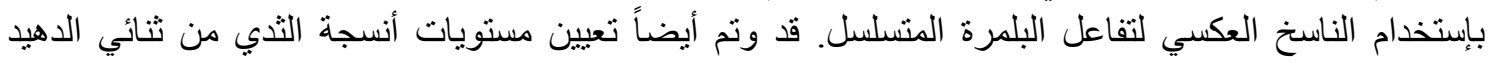

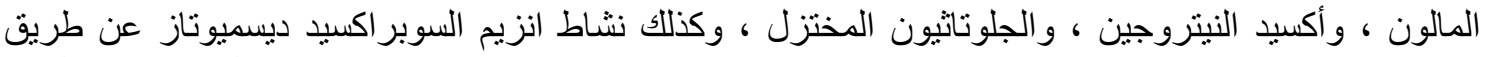

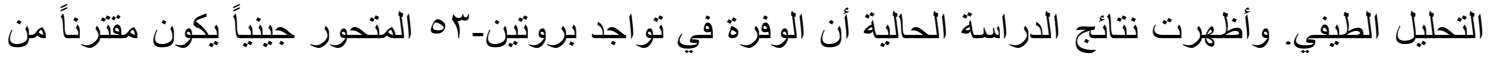

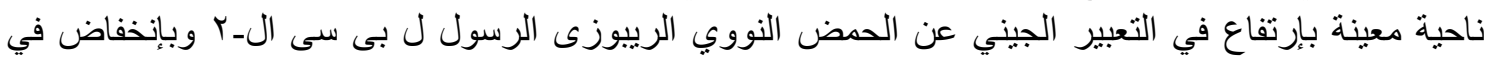

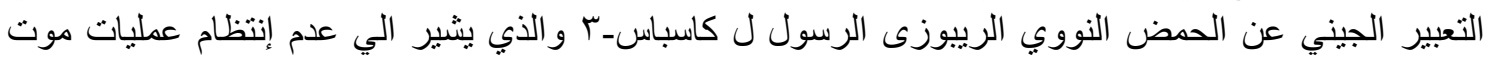

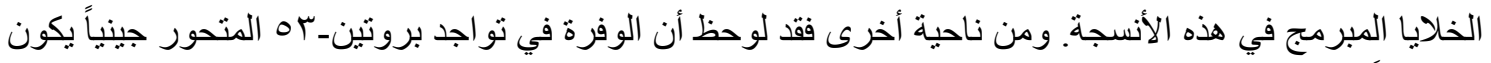

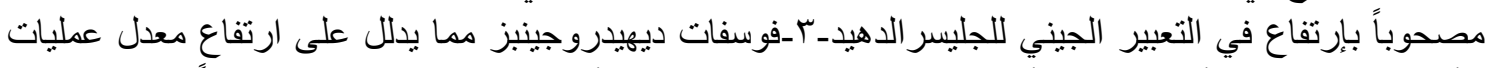

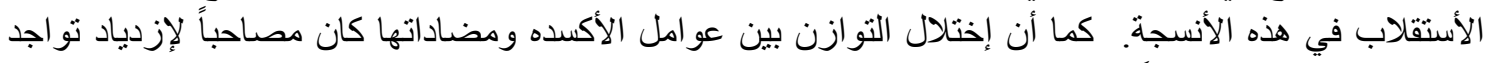

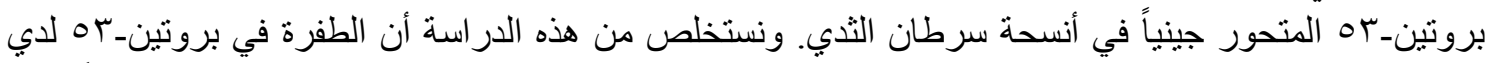

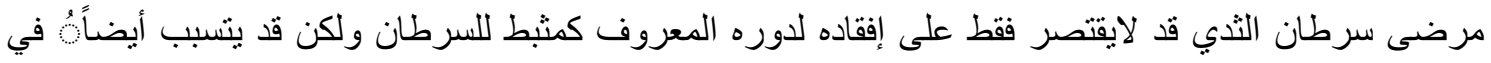

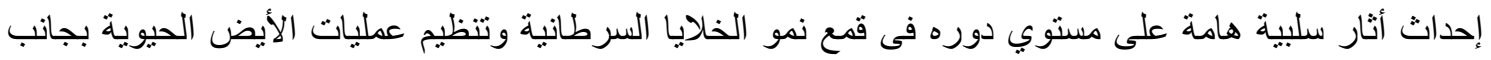

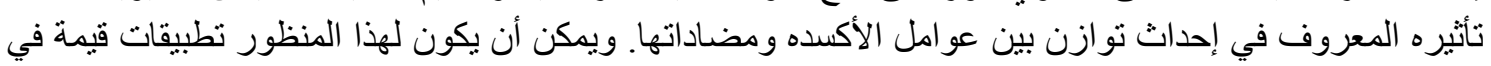
إيجاد طرق و اعدة لعلاج مرضى العئ الأور ام السرطانية. 